\title{
Determining the Soilborne Pathogens Associated with Root Rot Disease Complex of Dry Bean in Michigan
}

\author{
Janette L. Jacobs, ${ }^{1,+}$ James D. Kelly, ${ }^{1}$ Evan M. Wright, ${ }^{1}$ Gregory Varner, ${ }^{2}$ and Martin I. Chilvers ${ }^{1}$ \\ ${ }^{1}$ Department of Plant, Soil and Microbial Sciences, Michigan State University, East Lansing, MI \\ ${ }^{2}$ Michigan Dry Bean Production Research Advisory Board, Breckenridge, MI
}

Accepted for publication 18 April 2019.

\section{Abstract}

In Michigan, yield reduction as a result of diminished plant vigor owing to root rot is a major constraint associated with dry bean production and is exacerbated when fields have a history of short crop rotations. Replanting can be necessary when flooding, poor seed germination, or cool soil temperatures result in poor plant establishment, which may be compounded by increased disease pressure. To identify which soilborne pathogens are associated with root rot disease complex on dry bean and to determine their prevalence, a survey was conducted from 2014 to 2018. Dry beans with root rot symptoms were obtained from 39 field locations in 10 counties in Michigan. Rotted roots were washed, potential pathogens were cultured, and isolates were putatively identified into the major pathogen groups based on morphology. Additional identification was conducted with sequencing of the internal transcribed spacer of rDNA for oomycetes and Rhizoctonia and the translation elongation factor 1- $\alpha$ gene for Fusarium isolates. Among the 1,034 isolates obtained, Fusarium (54\%) was recovered at the highest prevalence, and oomycetes and Rhizoctonia exhibited a consistent presence, ranging across years from 11 to $30.2 \%$ and from 9.3 to $41.8 \%$, respectively. This survey provided baseline information on the prevalence of critical soilborne pathogens of dry bean in Michigan. In the future, additional genetic markers will be utilized to further identify organisms, a species characterization will be conducted to assess pathogenicity and virulence, and dry bean germplasm will be screened for resistance.

Keywords: Rhizoctonia, Fusarium, oomycetes, Phaseolus vulgaris
Michigan has a century-long history of dry bean (Phaseolus vulgaris L.) production, with archived records of production dating back to 1906 (Michigan Bean Company; Kelly 2010). Michigan was the number one producer of dry bean in the nation through the 1900s until 1991, when acreage in production declined with a corresponding increase in soybean acreage. Currently, the state ranks second in dry bean production in the United States, with approximately 190,000 acres planted in 2018 (USDA-NASS 2018). Michigan leads the nation in acreage of black and cranberry bean market classes, with lesser acreages of navy, small red, light red kidney, dark red kidney, and pinto beans. There are approximately 1,100 dry bean growers in the state, although about 275 growers produce $90 \%$ of the acreage grown (Gregory Varner, personal communication). Dry beans are planted in late spring, when soil temperatures reach at least $15^{\circ} \mathrm{C}$, because germination is slow and poor when soil temperatures are below $15^{\circ} \mathrm{C}$. The ideal temperature range for seed germination ranges from 21 to $27^{\circ} \mathrm{C}$. Days to emergence is 8 to 10 ; however, germination may take 2 weeks or more if soil temperatures are below $15^{\circ} \mathrm{C}$.

\section{${ }^{\dagger}$ Corresponding author: J. L. Jacobs; E-mail: jacobs90@msu.edu}

Funding: The authors acknowledge funding support from Project GREEENMichigan State University, the Michigan Department of Agriculture and Rural Development, and the Michigan Bean Commission. This work was also supported in part by the USDA National Institute of Food and Agriculture, Hatch project 1009212.

The author(s) declare no conflict of interest.

(C) 2019 The American Phytopathological Society
Cool soil temperatures can lead to increased seed rotting owing to soilborne pathogens that are more virulent under cooler temperature conditions (Kumar and Kudada 2018; Sippell and Hall 1982). The most important disease problem recognized by Michigan growers in dry bean production is white mold, caused by Sclerotinia sclerotiorum. However, plant stand establishment associated with seed rotting, damping-off, and root rot is considered the number two disease concern for growers. Unlike white mold, which is caused by a single pathogen, seed rot, damping-off, and root rot may be caused by a complex of soilborne pathogens. The main documented groups of fungal and oomycete pathogens causing seed and root rot symptoms on $P$. vulgaris worldwide include members of the genera Aphanomyces, Fusarium, Macrophomina, Pythium, Rhizoctonia, Sclerotium, Sclerotinia, and Thielaviopsis (Bilgi et al. 2008, 2011; Burkholder 1919; Harveson 2011; Harveson et al. 2005; Olson et al. 2016; Rusuku et al. 1997; Schwartz 2011; Sendi et al. 2018; Steadman et al. 1975; Yang and Hagedorn 1966). Root rot diseases incited by Fusarium and Pythium usually involve multiple species (Drechsler 1952; Gambhir et al. 2008; Hoch et al. 1975; Li et al. 2014; Rossman et al. 2017; Zitnick-Anderson et al. 2018), and Rhizoctonia includes heterogenous binucleate and multinucleate anastomosis groups (Hanson and Minier 2016; Muyolo et al. 1993).

Disease severity, as a result of these soilborne pathogens, varies with location and year owing to alterations in climatic, edaphic, pathogen, and host factors. Seed rot and preemergence or postemergence damping-off can result in thin, uneven plant stands; however, compensation by surviving plants can counteract losses in stand caused by pathogens (van Bruggen et al. 1986). Surviving infected bean roots elicit a defense mechanism when triggered by 
soilborne pathogens, resulting in an altered root architecture. Secondary roots arise from the infected root-shoot transition zone, with the primary root often dying owing to infection. This change in root architecture creates a horizontal versus a vertical orientation (Jackson 1955). The development of these secondary roots aid in plant survival, outgrowing the soilborne pathogens and allowing acquisition of available nutrients (Burke and Barker 1966; Snapp et al. 2003). However, infections that develop more slowly or later in seedling development can reduce root volume, result in plant stunting, and can potentially reduce yield. There have been negative correlations between yield and the presence of root rot symptoms in dry bean (Naseri and Marefat 2011; Sanchez-Anguinano and Cardenas-Alonso 1988). However, yield loss as a result of soilborne pathogens can be difficult to assess, in a large part because roots are rarely examined unless there is substantial impact to the plant canopy, and even severe root rot symptoms are often underreported or go unnoticed because affected plants are unevenly distributed within a field.

Michigan growers tend to use a 3-year rotation cropping system, with $90.3 \%$ of growers including dry bean in their planting acreage every year (Michigan Production Research Advisory Board 2018). The long history of dry bean cultivation in the state and practice of short crop rotations have promoted the build-up of damaging levels of soilborne root rot pathogens present in the majority of fields each year. Root disease severity development increases when roots are unable to outgrow the pathogens as a result of adverse edaphic conditions. Low soil temperatures, flooded or water-saturated conditions, and soil compaction can inhibit root growth and predispose roots to pathogen infection (Cichy et al. 2007; RománAvilés et al. 2004).

The lack of understanding of mechanisms of resistance expressed in dry bean roots to the vast diversity of soilborne pathogens present is a major reason for the difficulty in breeding for resistance. Quantitative knowledge on root system traits and the identification of quantitative trait loci associated with root rot resistance would improve selection criteria (Román-Avilés and Kelly 2005; RománAvilés et al. 2004; Singh and Schwartz 2010). With only partially resistant cultivars available, most growers rely heavily on seed treatments to combat soilborne diseases. Approximately $90 \%$ of Michigan growers report using treated seed, with the most common seed treatment (used by $54.8 \%$ of growers) including a cocktail of mefenoxam, fludioxonil, azoxystrobin, and ipconazole fungicides and the insecticide thiamethoxam (Michigan Production Research Advisory Board 2018).

It is important to know what soilborne pathogens are responsible for disease symptoms within individual fields to aid in improved management decisions, such as cultivar selection or seed treatment. Knowledge of the correct pathogen(s) also assists dry bean breeders in disease resistance phenotyping of breeding lines for development and release. However, it is extremely difficult to diagnose what pathogen(s) are responsible for root rot when only relying on visual symptoms. The objectives of this research were to (i) conduct a field survey to determine the diversity of soilborne pathogens associated with dry bean roots, (ii) identify the major root rot pathogen groups, and (iii) determine the prevalence of these major pathogen groups in Michigan.

\section{Determining the Diversity of Soilborne Pathogens Associated with Root Rot Disease Complex on Dry Bean}

Survey sample collection and identification of isolates. Throughout the 5-year survey period from 2014 to 2018, fields were selected based on a history of extended dry bean production and root rot issues. A total of 39 fields were sampled across 10 counties.
The numbers of fields by county were as follows: Alcona, 3; Bay, 2; Gratiot, 3; Huron, 3; Ingham, 4; Montcalm, 11; Presque Isle, 4; Saginaw, 5; Sanilac, 2; and Tuscola, 2 (Fig. 1). The fields were sampled throughout the growing season from the V1 (end of June) to the V5 or R1 (flowering) growth stage (early August) in indeterminate vine or bush cultivars, respectively. At each field visit, diseased plants were detected by scouting for symptoms while walking in a $\mathrm{W}$-shaped pattern. An individual symptomatic plant was randomly selected at different locations within each field and dug up with a shovel, shoots were excised, and roots were placed into a plastic bag and transported to the laboratory in a cooler on ice and stored at $4^{\circ} \mathrm{C}$. The number of plant samples collected at each location ranged from 1 to 34 and was dependent on disease severity presence in the field. Root samples were processed for isolation of organisms within $24 \mathrm{~h}$ postcollection. Root samples were prepared for isolation by washing them under running tap water for 10 to 20 min until all visible soil was removed. Roots were then patted dry with sterile paper towel to remove excess water, and 0.5 - to $1-\mathrm{cm}$ root or lower stem pieces of symptomatic tissue were excised using a sterile scalpel (Fig. 2). The excised tissue was placed onto semiselective culture medium. We used corn meal agar amended with pentachloronitrobenzene (50 $\mathrm{mg} / \mathrm{liter})$, ampicillin $(250 \mathrm{mg} /$ liter), rifampicin (10 mg/liter), pimaricin ( $5 \mathrm{mg} / \mathrm{liter})$, and benomyl (10 mg/liter) (CMA-PARPB) (Jeffers and Martin 1986) for isolation of oomycetes and water agar (WMS) amended with metalaxyl (15 mg/liter) and streptomycin (300 mg/liter) for isolation of fungi. Culture plates were incubated for 7 to 10 days at $20^{\circ} \mathrm{C}$ and

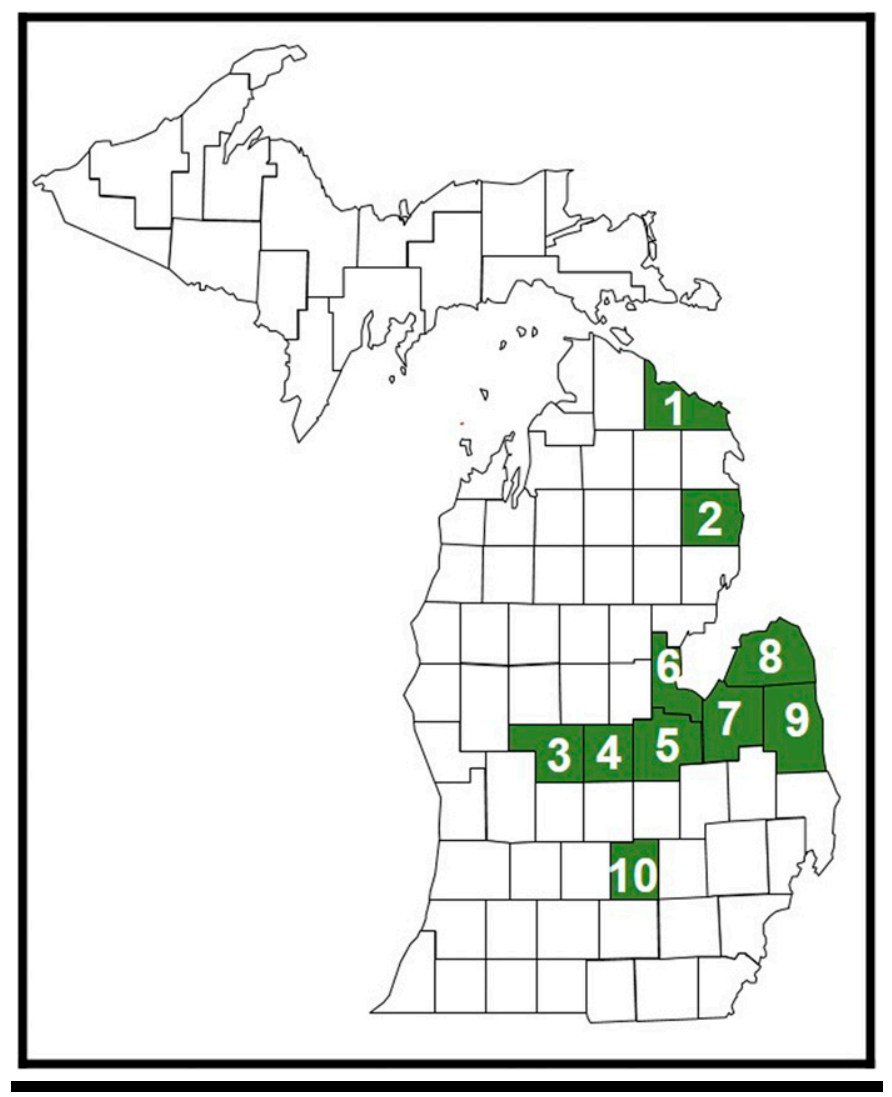

FIGURE 1

Locations of counties in Michigan where dry bean fields were sampled: $1=$ Presque Isle; 2 = Alcona; 3 = Montcalm; $4=$ Gratiot; $5=$ Saginaw; $6=$ Bay; 7 = Tuscola; 8 = Huron; $9=$ Sanilac; and $10=$ Ingham. 
checked daily for hyphal growth. If oomycete or fungal mycelial growth was observed, cultures were transferred to fresh CMAPARPB or potato dextrose agar (PDA) medium, respectively, by hyphal tip culturing. To recover slow-growing Fusarium solani species complex organisms, cultured root or stem pieces on both CMA-PARPB and WMS culture plates were examined using a dissecting microscope on a daily basis from 5 to 10 days postisolation for the development of sporodochia on infected plant tissue. If a sporodochium was present, a sterile insect pin was touched on the surface, enabling transfer to a clean WMS plate, and macroconidia were spread across the surface of the plate with a sterile inoculating loop. Plates were examined between 8 and $24 \mathrm{~h}$ posttransfer using a dissecting microscope for germination of macroconidia. A single germinating macroconidium was transferred with a sterile insect pin to a new PDA plate. Purified isolates were long-term stored by placing oomycete cultures on potato carrot agar slants and hemp seed vials (Erwin and Ribeiro 1996; van der Plaats-Niterink 1981), and fungi were placed on Spezieller Nahrstoffarmer agar (Leslie and Summerell 2006) slants and on filter paper. Five 5-mm plugs from fresh oomycete or fungal cultures were transferred into $50 \mathrm{ml}$ of $10 \% \mathrm{~V} 8$ or potato dextrose broth, respectively, in 125-ml Erlenmeyer flasks and incubated for 7 to 10 days at room temperature without agitation. Mycelia were
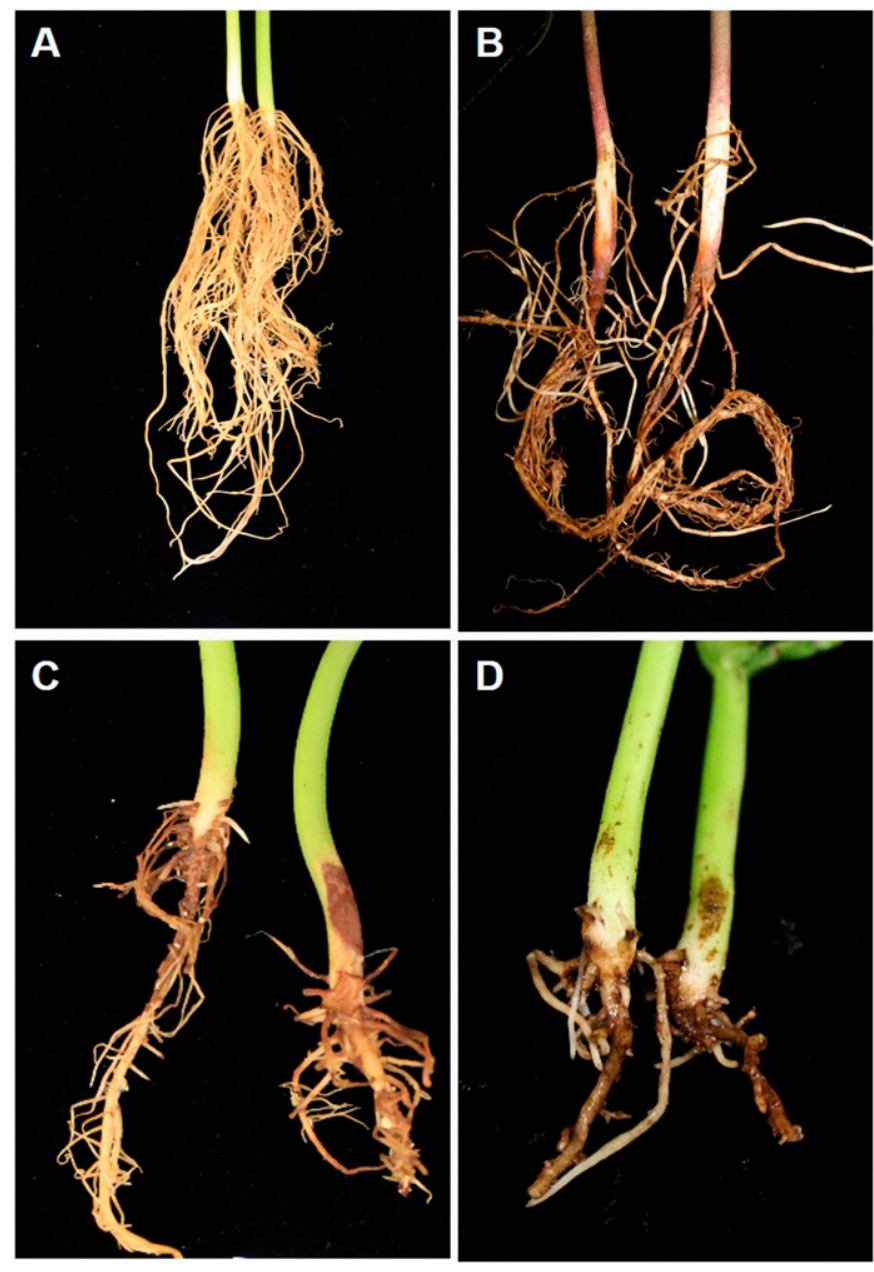

FIGURE 2

Representative root rot symptoms on dry bean: A, healthy root; B, Fusarium root rot; $\mathbf{C}$, Rhizoctonia root rot; and $\mathbf{D}$, Pythium root rot. harvested from broth cultures, lyophilized for $48 \mathrm{~h}$, and ground for DNA extraction. The DNA was extracted using a cetyltrimethylammonium bromide protocol; briefly, $20 \mathrm{mg}$ of ground mycelia was incubated in lysis buffer for $1 \mathrm{~h}$ at $37^{\circ} \mathrm{C}$, followed by phenol/chloroform/isoamyl alcohol DNA extraction. The DNA was then resuspended in Tris-ethylenediaminetetraacetic acid buffer, incubated on an orbital shaker for $1 \mathrm{~h}$, transferred to 1.5-ml tubes, and stored at $-20^{\circ} \mathrm{C}$.

Initial identification of isolated organisms was based on colony morphology and mycelial growth rate in culture, followed by morphological characteristics of hyphae, conidia, and reproductive structures, if present. Genetic analysis was used to confirm identity of the different organisms. Oomycetes, Macrophomina, Rhizoctonia solani, and Thielaviopsis were identified using the internal transcribed spacer (ITS) of rDNA by amplification with primers ITS1 and ITS4 (Cooke et al. 2000). The polymerase chain reaction (PCR) amplification reactions consisted of a final concentration of $1 \times$ PCR buffer (Invitrogen, Carlsbad, CA), $1.5 \mathrm{mM} \mathrm{MgCl}, 0.2 \mathrm{mM}$ dNTPs, $0.4 \mu \mathrm{M}$ ITS1, and $0.4 \mu \mathrm{M}$ ITS4 primers, $200 \mu \mathrm{g}$ of bovine serum albumin (BSA), $0.04 \mathrm{U}$ of Invitrogen Taq polymerase, and $1 \mu \mathrm{l}$ of template DNA. The amplification program consisted of an initial denaturation at $94^{\circ} \mathrm{C}$ for 5 min; 35 cycles of $94^{\circ} \mathrm{C}$ for $1 \mathrm{~min}, 60^{\circ} \mathrm{C}$ for $1 \mathrm{~min}$, and $72^{\circ} \mathrm{C}$ for $1 \mathrm{~min}$; and a final extension at $72^{\circ} \mathrm{C}$ for $7 \mathrm{~min}$. Fusarium spp. were confirmed using the translation elongation factor $1-\alpha$ (O'Donnell et al. 1998). The PCR amplification reaction consisted of a final concentration of $1 \times$ Phusion HF reaction buffer (New England Biolabs, Ipswich, MA), $0.2 \mathrm{mM}$ dNTPs, $0.4 \mu \mathrm{M}$ EF1-F (5'-ATGGGTAGGAAGACAAGAC$3^{\prime}$ ) and $0.4 \mu \mathrm{M}$ EF2-R (5'-GGAAGTACCAGTGATCATGTT-3'), $200 \mu \mathrm{g}$ of BSA, $0.05 \mathrm{U}$ of Taq polymerase, and $1 \mu \mathrm{l}$ of template DNA. The amplification program consisted of an initial denaturation at $98^{\circ} \mathrm{C}$ for $30 \mathrm{~s} ; 35$ cycles of $98^{\circ} \mathrm{C}$ for $30 \mathrm{~s}, 60^{\circ} \mathrm{C}$ for $15 \mathrm{~s}$, and $72^{\circ} \mathrm{C}$ for $30 \mathrm{~s}$; and a final extension at $72^{\circ} \mathrm{C}$ for $5 \mathrm{~min}$.

PCR amplicons were purified by adding $5 \mu \mathrm{l}$ of a mixture of $3 \mathrm{U}$ of exonuclease I and $0.5 \mathrm{U}$ of FastAP thermosensitive alkaline phosphatase (Thermo Scientific, Waltham, MA). Samples were incubated for $45 \mathrm{~min}$ at $37^{\circ} \mathrm{C}$, and enzymes were inactivated by incubation at $85^{\circ} \mathrm{C}$ for $10 \mathrm{~min}$. Amplicons were Sanger sequenced in both directions, and consensus sequences were assembled using CodonCode Aligner (https://www.codoncode.com/). Aligned sequences were queried against either a curated database of oomycete ITS sequences (Robideau et al. 2011) or compared with fungal DNA sequences using the Basic Local Alignment Search Tool (BLAST) program from the National Center for Biotechnology Information (https://blast.ncbi.nlm.nih.gov/Blast.cgi) by using the BLASTn search algorithm for identification (Altschul et al. 1990). Samples with a bitscore greater than 1,000 and identity greater than $97 \%$ were assigned to a taxonomic designation based on the BLAST output.

\section{Dry Bean Survey Summary}

Diversity and prevalence of pathogen groups associated with dry bean root rot complex. During the 5-year sampling period, 601 dry bean plant samples were collected from 39 field sites located in 10 counties within Michigan. The majority of plant samples harbored more than one of the major root rot-causing organisms, with the average isolate number ranging from 1.2 to 4.1 per plant sample, across sampling years. The percentage of Fusarium spp., R. solani, and oomycetes recovered from dry bean varied by year (Table 1). The percent recovery of Fusarium spp. across the years steadily increased from 38.1 to 74.3 ; these numbers could have been biased, because perhaps isolation skills associated with recovery of slower-growing $F$. solani species complex 
organisms could have improved over time. Other root rot studies conducted, however, also reported that Fusarium spp. were the predominant fungus isolated from dry bean (Adesemoye et al. 2018; Naseri 2008). The percentage of $R$. solani isolates recovered ranged from 9.3 to $41.8 \%$, with recovery highest in 2014. The high recovery, in 2014, was partially influenced by a single field that had a $72.1 \%$ recovery frequency. The percentage of oomycetes was more stable across the years, with a range of 11 to $30.2 \%$ recovery. Overall, the composition of soilborne pathogens associated with the roots of dry bean did not appear to be dependent on year or county, because all three major groups of pathogens were consistently recovered (Table 1). These findings are not surprising, because previous surveys conducted worldwide where $P$. vulgaris is cultivated (Hoch et al. 1975; Kobriger and Hagedorn 1984; Li et al. 2014; Sendi et al. 2018; Zitnick-Anderson et al. 2018) have found Fusarium spp., R. solani, and Pythium spp. to be the primary biotic factors associated with root rot of dry bean. Each field surveyed had its own unique composition of disease organisms, and, dependent on weather conditions and bean cultivar grown, resulted in some level of root rot present (Table 1). Individual field cropping history, edaphic factors, and localized environmental conditions may play a greater role in determining which pathogen will be present at a higher incidence (Abawi and Ludwig 2005). This definitely appears to be the case for the other root rot disease-causing organisms, Macrophomina phaseolina and Thielaviopsis basicola, which were not recovered each year and only from a limited number of fields. M. phaseolina was isolated in 2015 and 2017, at a 3\% frequency both years, and T. basicola was isolated only in 2018 from the two most northern counties sampled at a frequency of $2 \%$. Across all 5 years, the consistent presence of Fusarium spp., R. solani, and oomycete pathogens recovered at a high incidence warrants employment of management strategies. Growers should utilize seed treatments that target these three main groups of pathogens, implement a longer and more varied crop rotation, and select cultivars with tolerance to root rot organisms. In addition, planting in cool soil temperatures and in compacted soil should be avoided, and seeds should be sown at a proper planting depth, to provide a favorable soil microclimate for rapid seedling emergence and development (Sippell and Hall 1982; Valenciano et al. 2006).

Pathogens such as $R$. solani and certain Pythium spp. are generally thought to be more of an issue during plant establishment, causing seed rot and damping-off of emerging seedlings, resulting in stand loss (Conner et al. 2014). However, infection by $R$. solani can also result in the formation of stem cankers (Fig. 2). The diversity of $R$. solani multinucleate and binucleate anastomosis groups causing disease symptoms on dry bean has not been well studied. An anastomosis grouping study of $R$. solani isolates recovered from dry bean in Ohio and Zaire identified AG-2-2 and AG-4, respectively (Muyolo et al. 1993). Engelkes and Windels (1996) also reported on the susceptibility of dry bean and sugar beet to AG-2-2. A more recent study in Nebraska identified the multinucleate AG-2-2, AG-4, and AG-5 and the binucleate AG-K (Adesemoye et al. 2018). Within the AG-2-2, several subgroups (AG-2-2 IIIB, AG-2-2 IV, and AG-2-2 WB) have been reported based on host range and symptoms; however, these subgroups are not phylogenetically supported (Hanson and Minier 2016; Martin et al. 2012). Çebi Kiliçoğlu and Özkoç (2013) conducted a phylogenetic analysis of AG-4 and found subgroups HG-I and HG-II on bean in Turkey. Further work is necessary to identify the genetic diversity associated with $R$. solani anastomosis groups, evaluate

TABLE 1

\begin{tabular}{|c|c|c|c|c|c|c|c|}
\hline \multirow[b]{2}{*}{ Year } & \multirow[b]{2}{*}{ County } & \multirow{2}{*}{$\begin{array}{l}\text { Number } \\
\text { of sites }\end{array}$} & \multirow{2}{*}{$\begin{array}{c}\text { Number of } \\
\text { plant samples }\end{array}$} & \multicolumn{3}{|c|}{ Number (percentage) of isolates } & \multirow{2}{*}{$\begin{array}{l}\text { Total number } \\
\text { of isolates }\end{array}$} \\
\hline & & & & Fusarium spp. & Rhizoctonia solani & Oomycetes & \\
\hline \multirow[t]{3}{*}{2014} & Ingham & 1 & 34 & $10(43.5)$ & $5(21.7)$ & $8(34.8)$ & 23 \\
\hline & Montcalm & 4 & 46 & $32(45.1)$ & $22(31.0)$ & $17(23.9)$ & 71 \\
\hline & Saginaw & 1 & 34 & $10(23.3)$ & $31(72.1)$ & $2(4.6)$ & 43 \\
\hline \multirow[t]{5}{*}{2015} & Gratiot & 2 & 41 & $35(67.3)$ & $8(15.4)$ & $9(17.3)$ & 52 \\
\hline & Huron & 3 & 68 & $47(43.5)$ & $31(28.7)$ & $30(27.8)$ & 108 \\
\hline & Ingham & 1 & 10 & $7(35.0)$ & $4(20)$ & $9(17.3)$ & 20 \\
\hline & Montcalm & 3 & 97 & $45(34.5)$ & $41(31.2)$ & $45(34.4)$ & 131 \\
\hline & Saginaw & 4 & 89 & $52(47.7)$ & $19(17.4)$ & 38 (34.9) & 109 \\
\hline \multirow{2}{*}{2016} & Ingham & 1 & 3 & $0(0.0)$ & $0(0.0)$ & $4(100.0)$ & 4 \\
\hline & Total & 4 & 33 & $45(63.4)$ & $15(21.1)$ & $11(15.5)$ & 71 \\
\hline \multirow[t]{4}{*}{2017} & Ingham & 1 & 10 & $22(88.0)$ & $3(12.0)$ & $0(0.0)$ & 25 \\
\hline & Montcalm & 4 & 38 & $49(52.1)$ & $11(11.7)$ & $34(36.2)$ & 94 \\
\hline & Tuscola & 2 & 45 & $82(76.7)$ & $7(6.5)$ & $18(16.8)$ & 107 \\
\hline & Total & 7 & 93 & $153(67.7)$ & $21(9.3)$ & $52(23.0)$ & 226 \\
\hline \multirow[t]{3}{*}{2018} & Alcona & 3 & 10 & $33(70.2)$ & 7 (14.9) & 7 (14.9) & 47 \\
\hline & Presque Isle & 4 & 25 & $74(76.3)$ & $14(14.4)$ & $9(9.3)$ & 97 \\
\hline & Total & 7 & 35 & 107 (74.3) & $21(14.6)$ & $16(11.1)$ & 144 \\
\hline
\end{tabular}


pathogenicity across the genetic diversity, and determine the various edaphic and climatic conditions that influence distribution of this important soilborne pathogen.

Until recently, there were only older and limited studies focusing on specific oomycetes causing seed or root rot on dry bean. For example, Aphanomyces euteiches is well documented to cause root rot on a wide range of legumes (Hughes and Grau 2007) and has been identified as a major causal agent of root rot in pulse crops in the northern Great Plains and Canada, and it is widely distributed across the region (Chatterton et al. 2015; Gossen et al. 2016; Hagerty et al. 2015). There have been reports of specific species, such as $P$. aphanidermatum (Harter and Whitney 1927; Porch et al. 2014), P. myriotylum (Drechsler 1952; Gay and McCarter 1968), $P$. splendens (Binagwa et al. 2016), and P. ultimum (Abawi et al. 1985; Drechsler 1952; Kraft and Burke 1971; Wolock et al. 1983) all causing root rot of $P$. vulgaris. A more recent survey conducted in western Australia found eight different Pythium spp. (P. conidiophorum, $P$. diclinum, $P$. intermedium, $P$. irregulare, $P$. lutarium, $P$. mamillatum, $P$. pachycaule, and $P$. perplexum) associated with seedling rot and hypocotyl diseases of bean (Li et al. 2014). A pathogenicity evaluation of 28 oomycete species by Rossman et al. (2017) found 14 species to be pathogenic, with P. aphanidermatum, $P$. myriotylum, $P$. ultimum, $P$. ultimum var. sporangiiferum, and $P$. ultimum var. ultimum as the most virulent species causing seed rot and pre-emergence damping off. Phenotyping pathogenicity and fungicide sensitivity of a wide range of oomycetes on dry bean would be beneficial for selection of fungicide seed treatments and to provide breeders with information on which oomycetes to use in screening breeding populations.

Fusarium spp. are ubiquitous, having worldwide distribution as soilborne organisms wherever P. vulgaris is cultivated (Macedo et al. 2017). The Fusarium genus includes a wide range of species that have been associated with the roots of dry beans (Sendi et al. 2018); however it is the $F$. solani species complex clade 2 ( $F$. phaseoli, $F$. cuneirostrum, and $F$. brasiliense) that tends to cause the greatest severity of root rot in dry beans (Henriquez et al. 2014; Huber 1963; Keenan et al. 1974; Saettler 1978). The species $F$. acuminatum, $F$. avenaceum, $F$. culmorum, $F$. equiseti, $F$. graminearum, $F$. incarnatum, $F$. nygamai, $F$. redolens, $F$. semitectum, $F$. sickle, and $F$. sporotrichioides have all been found to be associated with the roots of dry bean (Adesemoye et al. 2018; Conner et al. 2014; Dhingra and Muchovej 1979; Goswami et al. 2010; ZitnickAnderson et al. 2018). Additional characterization of these various species in pathogenicity, fungicide sensitivity, and disease resistance in commercial dry bean cultivars would be beneficial to our knowledge base. F. oxysporum has been well documented as a wilt pathogen on dry bean, with symptoms of leaf yellowing, premature foliar senescence, vascular discoloration, and plant wilting, resulting in potential plant death (Abawi and Pastor-Corrales 1990; Brick et al. 2006).

\section{Significance and Future Studies}

This survey provided baseline information regarding the prevalence of critical soilborne pathogens associated with commercial dry bean production in Michigan. Future work will focus on use of additional genetic markers to identify organisms to the species level. Phenotypic characterization will be conducted to assess pathogenicity and virulence of these organisms on dry bean. In addition, collaborative efforts with dry bean breeders will focus on phenotypic screening of bean germplasm using characterized isolates of specific pathogens to identify and track resistance traits in segregating populations and develop linked marker systems to aid in selection for resistance.

\section{Literature Cited}

Abawi, G. S., Crosier, D. C., and Cobb, A. C. 1985. Root rot of snap beans in New York. New York's Food and Life Sciences Bulletin, No. 110. New York State Experimental Station, Geneva, NY.

Abawi, G. S., and Ludwig, J. W. 2005. Effect of three crop rotations with and without deep plowing on root rot severity and yield of beans. Ann. Rep. Bean Improv. Coop. 48:118-119.

Abawi, G. S., and Pastor-Corrales, M. A. 1990. Root Rots of Beans in Latin American and Africa: Diagnosis, Research Methodologies, and Management Strategies. CIAT, Cali, Colombia.

Adesemoye, A. O., Orrell, T., and Kodati, S. 2018. Effect of virulence of root rot pathogens and cultivar resistance on disease occurrence in dry beans. Plant Health Prog. 19:237-241.

Altschul, S. F., Gish, W., Miller, W., Myers, E. W., and Lipman, D. J. 1990. Basic Local Alignment Search Tool. J. Mol. Bio. 215:403-410.

Bilgi, V. N., Bradley, C. A., Khot, S. D., Grafton, K. F., and Rasmussen, J. B. 2008. Response of dry bean genotypes to Fusarium root rot, caused by Fusarium solani f. sp. phaseoli, under field and controlled conditions. Plant Dis. 92:1197-1200.

Bilgi, V. N., Bradley, C. A., Mathew, F. M., Ali, S., and Rasmussen, J. B. 2011. Root rot of dry edible bean caused by Fusarium graminearum. Plant Health Prog. 12. doi: 10.1094/PHP-2011-0425-01-RS.

Binagwa, R., Bonsi, C. K., and Nsolla, S. N. 2016. Evaluation of common bean (Phaseolus vulgaris) genotypes for resistance to root rot disease caused by Pythium aphanidermatum and Pythium splendens under screen house conditions. J. Nat. Sci. Res. 6:36-43.

Brick, M. A., Byrne, P. F., Schwartz, H. F., Ogg, J. B., Otto, K., Fall, A. L., and Gilbert, J. 2006. Reaction to three races of Fusarium wilt in the Phaseolus vulgaris core collection. Crop Sci. 46:1245-1252.

Burke, D. W., and Barker, A. W. 1966. Importance of lateral roots in Fusarium root rot of beans. Phytopathology 56:292-294.

Burkholder, W. H. 1919. The dry root-rot of bean. Mem. Cornell Univ. Agric. Exp. Stn. 26:1003-1033.

Çebi Kiliçoğlu, M., and Özkoç, İ. 2013. Phylogenetic analysis of Rhizoctonia solani AG-4 isolates from common beans in Black Sea coastal region, Turkey, based on ITS-5.8S rDNA. Turk. J. Biol. 37:18-24.

Chatterton, S., Bowness, R., and Harding, M. W. 2015. First report of root rot of field pea caused by Aphanomyces euteiches in Alberta, Canada. Plant Dis. 99: 288.

Cichy, K., Snapp, S. S., and Kirk, W. W. 2007. Fusarium root rot incidence and root system architecture in grafted common bean lines. Plant Soil 300: 233-244.

Conner, R. L., Hou, A., Balasubramanian, R., McLaren, D., and McRae, K. B. 2014. Reaction of dry bean cultivars grown in western Canada to root rot inoculation. Can. J. Plant Sci. 94:1219-1230.

Cooke, D. E. L., Drenth, A., Duncan, J. M., Wagels, G., and Brasier, C. M. 2000. A molecular phylogeny of Phytophthora and related oomycetes. Fungal Genet. Biol. 30:17-32.

Dhingra, O. D., and Muchovej, J. J. 1979. Pod rot, seed rot, and root rot of snap bean and dry bean caused by Fusarium semitectum. Plant Dis. Rep. 63:84-87.

Drechsler, C. 1952. Bean stem rot in Maryland and Delaware caused by several Pythium species. Plant Dis. Rep. 36:13.

Engelkes, C. A., and Windels, C. E. 1996. Susceptibility of sugar beet and beans to Rhizoctonia solani AG-2-2 IIIB and AG-2-2 IV. Plant Dis. 80:1413-1417.

Erwin, D. C., and Ribeiro, O. K. 1996. Phytophthora Diseases Worldwide. American Phytopathological Society, St. Paul. MN.

Gambhir, A., Lamppa, R. S., Rasmussen, J. B., and Goswani, R. S. 2008. Fusarium and Rhizoctonia species associated with root rots of dry beans in North Dakota and Minnesota. Phytopathology 98:S57.

Gay, J. D., and McCarter, S. M. 1968. Stem rot of snap bean in southern Georgia caused by Pythium myriotylum. Plant Dis. Rep. 52:416.

Gossen, B. D., Conner, R. L., Chang, K. F., Pasche, J. S., McLaren, D., Henriquez, M. A., Chatterton, S., and Hwang, S.-F. 2016. Identifying and managing root rot of pulses on the Northern Great Plains. Plant Dis. 100: 1965-1978.

Goswami, R. S., Gambhir, A., Chang, Y. W., and Lamppa, R. S. 2010. Dry edible bean pathogens prevalent in North Dakota with special emphasis on root rots. Annu. Rep. Bean Improv. Coop. 53:70-71.

Hagerty, C. H., Cuesta-Marcos, A., Cregan, P. B., Song, Q., McClean, R., Noffsinger, S., and Myers, J. R. 2015. Mapping Fusarium solani and 
Aphanomyces euteiches root rot resistance and root architecture quantitative trait loci in common bean. Crop Sci. 55:1969-1977.

Hanson, L. E., and Minier, D. 2016. Rhizoctonia solani: Understanding the terminology. Bean Improv. Coop. Annu. Rep. 58:x-xiii.

Harter, L. L., and Whitney, W. A. 1927. A transit disease of snap beans caused by Pythium aphanidermatum. J. Agric. Res. 34:443-447.

Harveson, R. M. 2011. Soilborne root and stem diseases of dry beans in Nebraska. Publication no. EC1869. University of Nebraska-Lincoln Extension, Lincoln, NB.

Harveson, R. M., Smith, J. A., and Stroup, W. W. 2005. Improving root health and yield of dry beans in the Nebraska panhandle with a new technique for reducing soil compaction. Plant Dis. 89:279-284.

Henriquez, M. A., McLaren, D. L., Conner, R. L., Balasubramanian, P. M., Chang, K. F., Hwang, S. F., and Strelkov, S. E. 2014. First report or Fusarium cuneirostrum causing root rot disease in dry bean (Phaseolus vulgaris) in Canada. Plant Dis. 98:278.

Hoch, H. C., Hagedorn, D. J., Pinnow, D. L. and Mitchell, J. E. 1975. Role of Pythium spp. as incitants of bean root and hypocotyl rot in Wisconsin. Plant Dis. Rep. 59:443-447.

Huber, D. M. 1963. Investigations on root rot of beans caused by Fusarium solani f. phaseoli. Ph.D. dissertation. Michigan State University, East Lansing, MI.

Hughes, T. J., and Grau, C. R. 2007. Aphanomyces root rot or common root rot of legumes. Plant Health Instructor.

Jackson, W. T. 1955. The role of adventitious roots in recovery of shoots following flooding of the original root system. Am. J. Bot. 42:816-819.

Jeffers, S. N., and Martin, S. B. 1986. Comparison of two media selective for Phytophthora and Pythium species. Plant Dis. 70:1038-1043.

Keenan, J. G., Moore, H. D., Oshima, N., and Jenkins, L. E. 1974. Effect of bean root rot on dryland pinto bean production in southwestern Colorado. Plant Dis. Rep. 58:890-892.

Kelly, J. D. 2010. One hundred years of bean breeding at Michigan State University: A chronology. Michigan State University AgBioResearch. https:// www.canr.msu.edu/beanbreeding/history/

Kobriger, K., and Hagedorn, D. J. 1984. Additional Pythium species associated with the bean root rot complex in Wisconsin's central sands. Plant Dis. 68:595-596.

Kraft, J. M., and Burke, D. W. 1971. Pythium ultimum as a root pathogen of beans and peas in Washington. Plant Dis. Rep. 55:1056-1060.

Kumar, M., and Kudada, N. 2018. Effect of sowing dates and weather conditions on Rhizoctonia root rot disease incidence and green pod yield of French bean. J. Phamacogn. Phytochem. 7:893-899.

Leslie, J. F., and Summerell, B. A. 2006. Page 6 in: The Fusarium Laboratory Manual. Blackwell Publishing, Ames, IA.

Li, Y. P., You, M. P., and Barbetti, M. J. 2014. Species of Pythium associated with seedling root and hypocotyl disease on common bean (Phaseolus vulgaris) in Western Australia. Plant Dis. 98:1241-1247.

Macedo, R., Sales, L. P., Yoshida, F., Silva-Abud, L. L., and Lobo, M. 2017. Potential worldwide distribution of Fusarium dry root rot in common beans based on the optimal environment for disease occurrence. PLoS ONE 12: $\mathrm{e} 0187770$

Martin, F. N., Windels, C. E., Brantner, J., and Hanson, L. E. 2012. Analysis of population structure and pathogenicity of Rhizoctonia solani AG 2-2 from Michigan, Minnesota and North Dakota. Sugarbeet Research Reports. Beet Sugar Development Foundation. (CD).

Michigan Bean Company. Records 1906-1980. Michigan State University Archives and Historical Collections, East Lansing, MI.

Michigan Production Research Advisory Board. 2018. Dry bean survey 2018. http://www.michiganbean.org

Muyolo, N. G., Lipps, P. E., and Schmitthenner, A. F. 1993. Anastomosis grouping and variation in virulence among isolates of Rhizoctonia solani associated with dry bean and soybean in Ohio and Zaire. Phytopathology 83:438-444.

Naseri, B. 2008. Root rot of common bean in Zanjan, Iran: Major pathogens and yield loss estimates. Australas. Plant Pathol. 37:546-551.

Naseri, B., and Marefat, A. 2011. Large-scale assessment of agricultural practices affecting Fusarium root rot and common bean yield. Eur. J. Plant Pathol. 131:179-195.

O’Donnell, K., Kistler, H. C., Cigelnik, E., and Ploetz, R. C. 1998. Multiple evolutionary origins of the fungus causing Panama disease of banana:
Concordant evidence from nuclear and mitochondrial gene genealogies. Proc. Natl. Acad. Sci. USA 95:2044-2049.

Olson, J. D., Damicone, J. P., and Kahn, B. A. 2016. Identification and characterization of isolates of Pythium and Phytophthora spp. from snap beans with cottony leak. Plant Dis. 100:1446-1453.

Porch, T. G., Valentin, S., Estevez de Jensen, C., and Beaver, J. S. 2014. Identification of soil-borne pathogens in a common bean root rot nursery in Isabela, Puerto Rico. J. Agric. Univ. P. R. 98:1-14.

Robideau, G. P., De Cock, A. W. A. M., Coffey, M. D., Voglmayr, H., Brouwer, H., Bala, K., Chitty, D. W., Désaulniers, N., Eggertson, Q. A., Gachon, C. M. M., Hu, C.-H., Küpper, F. C., Rintoul, T. L., Sarhan, E., Verstappen, E. C. P., Zhang, Y., Bonants, P. J. M., Ristaino, J. B., and Lévesque, C. A. 2011. DNA barcoding of oomycetes with cytochrome c oxidase subunit I and internal transcribed spacer. Mol. Ecol. Resour. 11:1002-1011.

Román-Avilés, B., and Kelly, J. D. 2005. Identification of quantitative trait loci conditioning resistance to Fusarium root rot in common bean. Crop Sci. 45: 1881-1890.

Román-Avilés, B., Snapp, S. S., and Kelly, J. D. 2004. Assessing root traits associated with root rot resistance in common bean. Field Crops Res. 86: $147-156$

Rossman, D. R., Rojas, A., Jacobs, J. L., Mukankusi, C., Kelly, J. D., and Chilvers, M. I. 2017. Pathogenicity and virulence of soilborne oomycetes on Phaseolus vulgaris. Plant Dis. 101:1851-1859.

Rusuku, G., Buruchara, R. A., Gatabazi, M., and Pastor-Corrales, M. A. 1997. Occurrence and distribution in Rwanda of soilborne fungi pathogenic to the common bean. Plant Dis. 81:445-449.

Saettler, A. W. 1978. Bean diseases and their control. Pages 172-179 in: Dry Bean Production: Principles and Practices. L. S. Robertson and R. D. Frazier, eds. MSU Cooperative Extension, East Lansing, MI.

Sanchez-Anguinano, J. H., and Cardenas-Alonso, M. 1988. Etiology and damage of root rot disease in beans (Phaseolus vulgaris L.) in the state of Durango. Revista Chapingo 12:43-49.

Schwartz, H. F. 2011. Root Rots of Dry Beans. Colorado State University Extension Fact Sheet No. 2.938.

Sendi, Y., Romdhane, S. B., Mhamdi, R., and Mrabet, M. 2018. Diversity and geographic distribution of fungal strains infecting field-grown common bean (Phaseolus vulgaris L.) in Tunisia. Eur. J. Plant Pathol. 153:947-955.

Singh, S. P., and Schwartz, H. F. 2010. Breeding common bean for resistance to diseases: A review. Crop Sci. 50:2199-2223.

Sippell, D. W., and Hall, R. 1982. Effects of pathogen species, inoculum concentration, temperature, and soil moisture on bean root rot and plant growth. Can. J. Plant Pathol. 4:1-7.

Snapp, S. S., Kirk, W. W., Roman-Aviles, B., and Kelly, J. D. 2003. Root traits play a role in integrated management of Fusarium root rot in snap beans. HortScience 38:187-191.

Steadman, J. R., Kerr, E. D., and Mumm, R. R. 1975. Root rot of bean in Nebraska: Primary pathogen and yield loss appraisal. Plant Dis. Rep. 59: 305-308.

U.S. Department of Agriculture, National Agricultural Statistics Service (USDA-NASS). 2018. https://quickstats.nass.usda.gov/

Valenciano, J. B., Casquero, P. A., Boto, J. A., and Marcelo, V. 2006. Evaluation of the occurrence of root rots on bean plants (Phaseolus vulgaris) using different sowing methods and with different techniques of pesticide application. N. Z. J. Crop Hortic. Sci. 34:291-298.

van Bruggen, A. H. C., Whalen, C. H., and Arneson, P. A. 1986. Effect of inoculum levels of Rhizoctonia solani on emergence, plant development, and yield of dry beans. Phytopathology 76:869-873.

van der Plaats-Niterink, A. J. 1981. Monograph of the Genus Pythium. Studies in Mycology, Vol 21. Centraalbureau voor Schimmelcultures, Baarn, The Netherlands.

Wolock, D. M., Whalen, C. H., and Arneson, P. A. 1983. Effects of Fusarium solani f. sp. phaseoli and Pythium ultimum on root rot and plant development of dry bean. Phytopathology 73:377.

Yang, S., and Hagedorn, D. J. 1966. Root rot of processing bean in Wisconsin. Plant Dis. Rep. 50:578-580.

Zitnick-Anderson, K., Simons, K., and Pasche, J. S. 2018. Detection and qPCR quantification of seven Fusarium species associated with the root rot complex in field peas. Can. J. Plant Pathol. 40:261-271. 